\title{
Valorization of calcium carbonate-based solid wastes for the treatment of hydrogen sulfide in a semi-continuous reactor
}

\author{
Marta Galera Martínez ${ }^{\mathrm{b}}$, Doan Pham Minh ${ }^{\mathrm{a}, \mathrm{b}, *}$, Ange Nzihou ${ }^{\mathrm{b}}$, Patrick Sharrock ${ }^{\mathrm{b}}$ \\ a Institute of Research and Development, Duy Tan University, Da Nang 550000, Viet Nam \\ ${ }^{\mathrm{b}}$ Université de Toulouse, IMT Mines Albi, CNRS UMR 5302, Centre RAPSODEE, Campus Jarlard, Albi F-81013 cedex 09, France
}

- Valorisation of $\mathrm{CaCO}_{3}$-containing solid wastes for $\mathrm{H}_{2} \mathrm{~S}$ removal from the gas phase.

- Design of a triphasic gas/liquid/solid process.

- Crucial importance of $\mathrm{H}_{2} \mathrm{~S}$ dissolution and dissociation steps in $\mathrm{CaCO}_{3}$ suspension.

- Oxidation of dissolved sulfur species into stable sulfite, sulfate, and thiosulfate.

- Understanding of the mechanism of $\mathrm{H}_{2} \mathrm{~S}$ removal by this triphasic process.

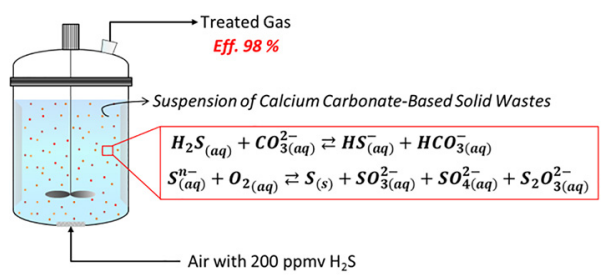

Keywords:

$\mathrm{H}_{2} \mathrm{~S}$ removal

Calcium carbonate

Triphasic process

Reaction pathway

The carbonation of residual brines generates large volumes of carbonate-based solid wastes. Physicochemical properties of these solids are adequate for acid-gas removal. This work studies the valorization of calcium carbonated-based solid wastes for efficient $\mathrm{H}_{2} \mathrm{~S}$ removal from air at low concentrations ( $\leq 200 \mathrm{ppmv}$ ) in a threephase semi-continuous reactor. Synthetic air polluted with $\mathrm{H}_{2} \mathrm{~S}$ was bubbled into the slurry of two different wastes in a stirred tank to evaluate their effect for $\mathrm{H}_{2} \mathrm{~S}$ removal. The efficiency of $\mathrm{H}_{2} \mathrm{~S}$ removal was kept constant and could reach up to $98 \%$ during $8 \mathrm{~h}$ of reaction. Adequate physico-chemical characterization of used sorbents allowed understanding the interaction of sulfide species with sorbent particles. Thus, the reaction pathway for $\mathrm{H}_{2} \mathrm{~S}$ removal was determined. It has been demonstrated that the dissolution of $\mathrm{H}_{2} \mathrm{~S}$ gas at the gas-liquid interface was then accelerated by high basicity of calcium carbonate-based wastes, followed by the oxidation of dissolved sulfide species. This last was catalyzed by metals and metals oxides which were initially present in the solid wastes. The results obtained demonstrate the possibility to valorize the carbonates which have been precipitated during the carbonation of industrial brines to develop a low cost $\mathrm{H}_{2} \mathrm{~S}$ removal process.

\section{Introduction}

Hydrogen sulfide $\left(\mathrm{H}_{2} \mathrm{~S}\right)$ is an acid gas pollutant released by several industrial process and agricultural activities. Some of them are petroleum refineries, natural gas plants, petrochemical plants, coke oven plants, biogas plants and geothermal power plants, pulp and paper operations, municipal sewers and sewage treatment plants, swine containment and manure-handling operations, food processing plants, tanneries, etc. [1-4]. $\mathrm{H}_{2} \mathrm{~S}$ emissions concentration varies in a large range from ppmv to volume percentages, which depends on the industrial facility. These emissions are considered as sources of obnoxious odors, perceptible even at very low levels. In fact, the odor threshold of

\footnotetext{
* Corresponding author at: Institute of Research and Development, Duy Tan University, Da Nang 550000, Viet Nam.

E-mail address: doan.phamminh@mines-albi.fr (D. Pham Minh).
} 
$\mathrm{H}_{2} \mathrm{~S}$ can range from $0.5 \mathrm{ppb}$ to $0.3 \mathrm{ppmv}$ [5] that usually causes a nuisance to neighbors of above-mentioned industrial sites. However, the perception of the odor disappears at higher concentrations (150-200 ppmv [5]) when the gas becomes an extreme health hazard. In fact, the exposure under these concentration levels for some hours is enough to produce severe and irreversible injuries or even death. Thus, smell is not a reliable indicator to recognize the presence of this toxic gas. $\mathrm{H}_{2} \mathrm{~S}$ is also associated with environmental problems. The oxidation of $\mathrm{H}_{2} \mathrm{~S}$ results in the release of sulfur dioxide $\left(\mathrm{SO}_{2}\right)$ that is the principal culprit of acid rain [6]. Even at lower concentration, in the order of dozens to hundreds of ppmv, $\mathrm{H}_{2} \mathrm{~S}$ causes extensive damage in piping and equipment by corrosion. This leads to a rise in maintenance cost due to repair or/and replacement of affected facilities.

Several methods for the $\mathrm{H}_{2} \mathrm{~S}$ treatment were studied. Standard technologies are chemical absorption using basic reactants and/or oxidizing agents, the adsorption on activated carbon or other adsorbents, and biological processes. The efficiency of these processes has been demonstrated at industrial pilot scale [7-9]. However, these processes still need to be improved, in particular to reduce operational cost and overcome limits of operation conditions. For example, the performance of biofilters depends strongly on the weather conditions because bacteria work under a determined temperature range $[10,11]$.

Several industrial processes (soda-ash process, oil and gas production, etc.) produce a large volume of residual brines with important amounts of calcium-rich and/or magnesium-rich minerals. The accelerated carbonation of these residual brines has been proposed as a method for $\mathrm{CO}_{2}$ sequestration. During this process, called "mineral carbonation", $\mathrm{CO}_{2}$ reacts with the alkali divalent cations $\mathrm{Ca}^{2+}$ and/or $\mathrm{Mg}^{2+}$ and their oxides ( $\mathrm{CaO}$ and/or $\mathrm{MgO}$ ) to produce carbonates particles that are stable at atmospheric conditions $[12,13]$. These carbonates can be valorized for acid gas neutralization in dry or semi-dry flue gas treatment $[14,15]$.

In this work, we show the efficiency of calcium carbonate-based solids, which have been precipitated during the carbonation of residual brines from industrial facilities, in triphasic gas-liquid-solid process for removing $\mathrm{H}_{2} \mathrm{~S}$ from the gas phase. Results obtained are very interesting from the performance standpoint. This offers the possibility for a future application at large pilot or industrial scale. The advantages of this process are triple: 1 ) The process uses environmentally-friendly materials taking into account the fact that carbonated-based solids are obtained by the stable sequestration of $\mathrm{CO}_{2}$ into alkaline residual streams. This reduces the $\mathrm{CO}_{2}$ emissions as the main greenhouse gas. 2) The carbonated-based solids can be valorized without further pre-treatment. This provides economic benefits. 3) $\mathrm{H}_{2} \mathrm{~S}$ is efficiently removed even at trace amount under ambient conditions of temperature and pressure from the air atmosphere. Thus this triphasic process is interesting for the treatment of $\mathrm{H}_{2} \mathrm{~S}$ emission from other sources, i.e. $\mathrm{H}_{2} \mathrm{~S}$ in biogas, natural gas or syngas from pyro-gasification of wastes and/or biomass.

\section{Materials and methods}

\subsection{Materials}

Two solid wastes containing mainly calcium carbonate were used. The first one was formed by slow and natural carbonation of residual brines with atmospheric $\mathrm{CO}_{2}$ for years. This solid is called thereafter NPC. The second one came from the artificial carbonation by $\mathrm{CO}_{2}$ bubbling of the similar residual brines. This solid is designated thereafter APC. Both solid wastes existed in fine powder form. After drying at room temperature, they are sieved to eliminate the eventual particles larger than $315 \mu \mathrm{m}$ (less than $1 \mathrm{wt} \%$ ). No further treatment was done before characterization and use in $\mathrm{H}_{2} \mathrm{~S}$ removal tests. A commercial calcium carbonate under fine powder form from Fischer Scientific (calcite, $\mathrm{CaCO}_{3},>98 \%$, ref. 10101710) was also used as reference material.

\subsection{Analysis and characterization}

Specific surface area was determined using the BET method. Samples were firstly degased in Micrometrics Vacprep 061. The adsorption-desorption isotherms were measured with a Micrometrics Tristar II 3020 using nitrogen as gas adsorbate. Scanning electron microscopy coupled with energy dispersive spectroscopy (SEM-EDX) was carried out on a Philips XL30 ESEM apparatus. Particle size distribution of solid powder was measured by laser scattering in a Mastersizer 3000 (Malvern Instruments Ltd) in the range of 0.020-2000 $\mu \mathrm{m}$. Infrared spectroscopy (IR) was recorded on a Shimadzu FTIR 8400 S spectrometer using a sensitive pyroelectric detector with an L-alanine-doped deuterated triglycine sulfate element. Thermogravimetry analysis (TG) was performed in a TA Instruments SDT Q600 analyzer with a heating rate of $5{ }^{\circ} \mathrm{C} / \mathrm{min}$ under air flux $\left(100 \mathrm{~mL} \mathrm{~min}^{-1}\right)$. X-rays diffraction of solid samples was carried out using a Phillips Panalytical X'pert Pro MPD diffractometer, equipped with a copper X-rays source $\left(K_{\alpha}\right.$ of $1.543 \AA$ ). The data were collected in the $2 \theta$ ranges from 10 to $75^{\circ}$ with a step size of $0.0167^{\circ}$. The identification of crystalline phases was based on the JCPDS database. Inductively coupled plasma atomic emission spectroscopy (ICP-AES) was performed using a HORIBA Jobin-Yvon Ultima 2. After test, the suspension was filtered and the liquid phase was analyzed by ion chromatography (ICS3000 DIONEX). Sulfide ( $\mathrm{S}^{2-}$ ) was measured with an amperometric detector using the column PA1 $(250 \times 4 \mathrm{~mm})$ and the mobile phase containing $0.1 \mathrm{M} \mathrm{NaOH}$ and $0.5 \mathrm{M}$ $\mathrm{CH}_{3} \mathrm{COONa}$ at the flow rate of $1 \mathrm{~mL} \mathrm{~min}{ }^{-1}$. Sulfite $\left(\mathrm{SO}_{3}{ }^{2-}\right)$, thiosulfate $\left(\mathrm{S}_{2} \mathrm{O}_{3}{ }^{2-}\right)$ and sulfate $\left(\mathrm{SO}_{4}{ }^{2-}\right)$ ions were measured with a conductimetric detector using the column AS11 $(250 \mathrm{~mm} \times 4 \mathrm{~mm})$ and the mobile phase containing $30 \mathrm{mM} \mathrm{KOH}$.

\section{3. $\mathrm{H}_{2} \mathrm{~S}$ removal test}

\subsubsection{Reactor and experimental procedure}

Tests were carried out in a $250 \mathrm{~mL}$ glass stirred reactor (Fig. 1). For a given test, the reactor was firstly purged with dry air flow containing 200 ppmv of $\mathrm{H}_{2} \mathrm{~S}$ (p.a. grade from Air Liquide), which is called thereafter waste air. It was fed to the reactor from the bottom via a porous glass disk. A desired volume of double-distilled water was fed into the reactor, under waste air flow $\left(100 \mathrm{~mL} \mathrm{~min}^{-1}\right)$ and under stirring (limited at $600 \mathrm{rpm}$ for the glass reactor used in this work). When the double-distilled water was saturated in $\mathrm{H}_{2} \mathrm{~S}$, a desired quantity of sorbent was added to the reactor to start the $\mathrm{H}_{2} \mathrm{~S}$ removal test.

Fig. 2 illustrates the different steps of a given $\mathrm{H}_{2} \mathrm{~S}$ removal test in this work.

In Fig. 2, Zone 1 corresponds to the purging step of the reactor with the waste air stream. Zone 2 shows the dissolution of $\mathrm{H}_{2} \mathrm{~S}$ in water, after filling the reactor with double-distilled water under stirring. When this water was saturated with $\mathrm{H}_{2} \mathrm{~S}$, sorption test was started by adding a sorbent to the reactor. The moment for solid addition to the reactor was considered as the zero time of $\mathrm{H}_{2} \mathrm{~S}$ removal test ( $t_{o}$, Fig. 2). Zone 3 corresponds to the abatement of $\mathrm{H}_{2} \mathrm{~S}$ by the sorbent added into the reactor. Typically, in Zone 3, the outlet concentration of $\mathrm{H}_{2} \mathrm{~S}$ abruptly

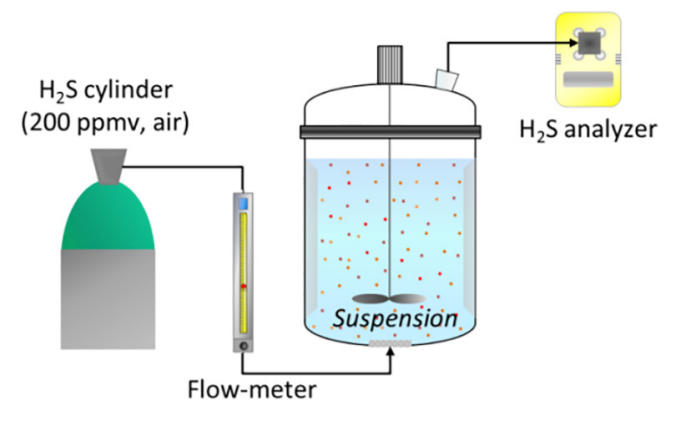

Fig. 1. Tri-phasic system for $\mathrm{H}_{2} \mathrm{~S}$ removal at laboratory scale. 


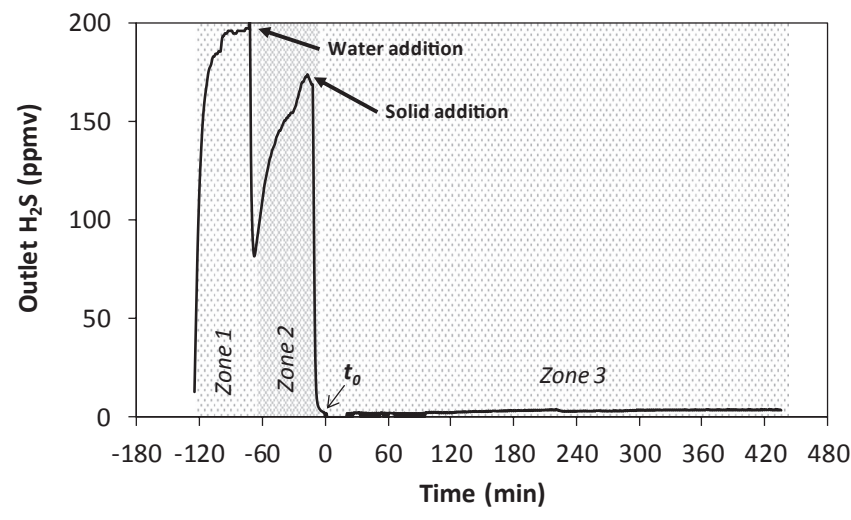

Fig. 2. Example of profile of $\mathrm{H}_{2} \mathrm{~S}$ concentration at the outlet of reactor. Conditions: gas flow rate of $100 \mathrm{~mL} \mathrm{~min}^{-1}$, inlet concentration of $\mathrm{H}_{2} \mathrm{~S}$ of 200 ppmv, $100 \mathrm{~mL}$ of suspension, $5 \mathrm{wt} \%$ of solid using APC as reactive sorbent, room temperature and pressure.

dropped to zero within less than 2 min. Then, a plateau of outlet $\mathrm{H}_{2} \mathrm{~S}$ concentration was observed. Within this plateau, the variation of outlet $\mathrm{H}_{2} \mathrm{~S}$ concentration was small $(+/-3 \mathrm{ppmv})$. This concentration was used to calculate the efficiency of $\mathrm{H}_{2} \mathrm{~S}$ removal (Eq. (1)).

The outlet concentration of $\mathrm{H}_{2} \mathrm{~S}$ was monitored every minute by a $\mathrm{H}_{2} \mathrm{~S}$ analyzer (Gas Alert QUATTRO, from BW Technologies). All the experiments were carried out at room temperature and atmospheric pressure. The $\mathrm{pH}$ of the suspension was measured at the beginning and at the end of each experiment. Each experiment was carried out for at least $8 \mathrm{~h}$ with a semi-continuous process, wherein the volume of the active medium (suspension of solid waste) is practically unchanged, while the waste air continuously passes through the suspension. Each test was repeated at least three times to verify the repeatability. The standard deviation was found to be smaller than $1 \%$.

For the study on the influence of experimental conditions on the removal of $\mathrm{H}_{2} \mathrm{~S}$, the efficiency of $\mathrm{H}_{2} \mathrm{~S}$ removal is defined by the following equation:

$\operatorname{Eff}(\%)=100 \times \frac{\left[\mathrm{H}_{2} S\right]_{G, i}-\left[\mathrm{H}_{2} S\right]_{G, o}}{\left[\mathrm{H}_{2} S\right]_{G, i}}$

where $\left[\mathrm{H}_{2} S\right]_{G, i}$ was the concentration of $\mathrm{H}_{2} \mathrm{~S}$ at the inlet of the reactor (200 ppmv); and $\left[H_{2} S\right]_{G, o}$ was the concentration of $\mathrm{H}_{2} \mathrm{~S}$ at the outlet of the reactor, after reaching the plateau as shown in Fig. 2.

\subsubsection{Choice of operational parameters}

According to the 'Arrhenius low', the kinetic constant of a reaction increases as temperature increases. Nevertheless, increasing the temperature has a negative effect on gas and solid solubility. As the temperature increases, the solubility of a gas decreases. Similarly, the solubility of calcite (the major component in the solid wastes) decreases as the temperature increases. In order to promote the mass transfer of the solid and the gas to the liquid phase, low temperatures are recommended. In this work, the ambient temperature was chosen.

Pressure does not significantly affect the calcite solubility. However, gas solubility is improved at higher pressures but this may result in higher operating and maintenance costs for industrial-scale applications. Thus, atmospheric pressure was chosen in view of the development of an economically-competitive process.

The optimal gas flow rate was obtained experimentally and set at $100 \mathrm{~mL} / \mathrm{min}$ for this triphasic reactor [16]. Lower values of the gas flow rate produced preferential flow paths in the gas diffuser (because of the various pore diameter of the glass porous disk), as well as solid decantation. For higher values the gas flow rate, the stirring speed should be increased to ensure good dispersion of the waste air in the liquid phase which increases operational cost. Moreover, the impact of the hydrodynamic of the system must be considered. If the stirring speed and the physicochemical properties of the suspension are supposed constant, an increase in the gas flow makes bubbles diameter larger and consequently the gas-liquid interfacial area $a$ is reduced (Eq. (3)). Also, a high gas flow rate increases the rising speed of bubbles thus the contact time between three phases is reduced. Both have a negative impact on the mass transfer and consequently on the efficiency of the process.

The Eq. (1) could be transformed as follows:

$E f f=\left(\mathscr{R} T / P_{H 2 S} Q_{G}\right) \mathscr{N}_{H 2 S}$

where $\mathrm{N}_{\mathrm{H} 2 \mathrm{~S}}$ is the rate of mass transfer of $\mathrm{H}_{2} \mathrm{~S}\left(\mathrm{~mol} \mathrm{H} \mathrm{H}_{2} \mathrm{~S} / \mathrm{s}\right)$ at a given time $t$ of the $\mathrm{H}_{2} \mathrm{~S}$ removal process, $P_{\mathrm{H} 2 \mathrm{~S}}$ is the partial pressure of $\mathrm{H}_{2} \mathrm{~S}$ in the inlet gas (atm), $Q_{G}$ is the volumetric flow rate of the gas $(\mathrm{L} / \mathrm{s}), \mathrm{R}$ is the universal gas constant $(0.0814 \mathrm{~atm} \mathrm{~L} / \mathrm{mol} \mathrm{K})$ and $T$ the temperature (K). At the same time, $\mathrm{N}_{H 2 S}$ is defined as follow $[17,18]$ :

$\mathscr{N}_{H 2 S}=K_{L} a\left(C_{L}^{E}-C_{L}\right) E V$

where $K_{L}$ is the liquid phase mass transfer $(\mathrm{m} / \mathrm{s}), a$ is the gas-liquid interfacial area per unit of volume $\left(\mathrm{m}^{2} / \mathrm{m}^{3}\right), \mathrm{C}_{\mathrm{L}}{ }^{\mathrm{E}}$ is the equilibrium concentration of $\mathrm{H}_{2} \mathrm{~S}$ in the liquid $\left(\mathrm{mol} / \mathrm{m}^{3}\right)$ and $\mathrm{C}_{\mathrm{L}}$ is the concentrations of $\mathrm{H}_{2} \mathrm{~S}$ in the bulk of the liquid $\left(\mathrm{mol} / \mathrm{m}^{3}\right), E$ is the enhancement factor by the solid and $V$ is the suspension volume. Mass transfer parameters as $K_{L}$ and $a$ are dependent of hydrodynamics. In consequence, some hydrodynamic parameters like stirring speed are also considered in the study.

In this work, stirring speed was varied from 200 to $600 \mathrm{rpm}$, which is the limit of the glass reactor. Other experimental parameters like the residues loading, the suspension volume, and the inlet concentration of $\mathrm{H}_{2} \mathrm{~S}$ were also investigated and are mentioned in the next sections.

\section{Results and discussion}

\subsection{Characterization of calcium carbonate-based solids}

Fig. 3 shows the particle size distribution of these three sorbents, obtained by the laser scattering (Mastersizer 3000, Malvern Instruments Ltd). Both solid wastes (APC and NPC) had the similar particle size distribution with different populations of particles, rising up to around $400 \mu \mathrm{m}$. On the other hand, the commercial calcite from Fisher Scientific contained smaller particles $(<35 \mu \mathrm{m})$ compared to the solid wastes with a bimodal distribution. In all cases, these solids are favorable for the preparation of aqueous suspension in batch reactor.

Table 1 shows that both solid wastes contained calcium carbonate as the main component. Several impurities were also present in these solid wastes. In most of cases, APC contained more impurities than NPC, except for Fe. In addition to these main elements, both APC and NPC contained other minerals at trace amounts including $\mathrm{Si}$ (up to $2000 \mathrm{ppm}$ ), $\mathrm{Al}, \mathrm{Zn}, \mathrm{Ni}$ and $\mathrm{Cu}$ (up to $100 \mathrm{ppm}$ ). The presence of chlorine was due to the residual $\mathrm{CaCl}_{2}$ and/or $\mathrm{NaCl}$ from the brine, which are all water soluble. NPC contained less chlorine than APC because NPC was landfilled for years and thus, most of chlorine compounds were leached under natural conditions. To check this hypothesis, aqueous

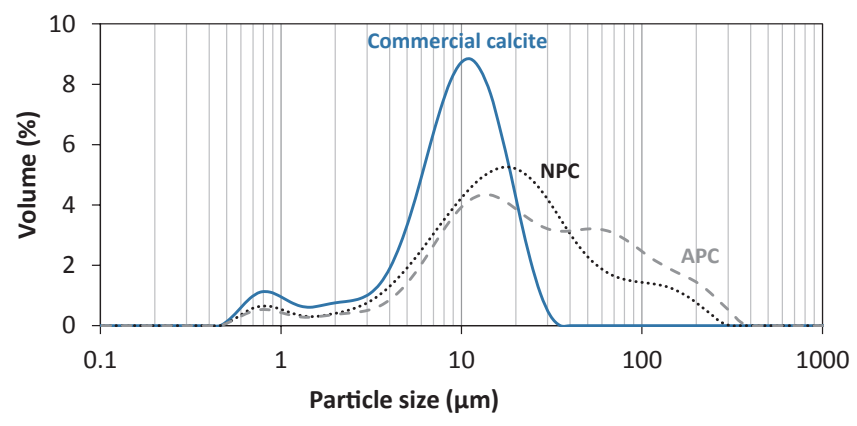

Fig. 3. Particle size distribution of the sorbents used in this work. 
Table 1

Chemical composition of APC and NPC obtained by ICP-AES and TG analyses.

\begin{tabular}{|c|c|c|c|c|c|c|}
\hline \multirow[t]{2}{*}{ Solid } & \multicolumn{6}{|c|}{ Concentration $\left(\mathrm{g} \mathrm{kg}^{-1}\right)$} \\
\hline & $\mathrm{Ca}$ & $\mathrm{CO}_{3}^{2-}$ & $\mathrm{S}$ & $\mathrm{Mg}$ & $\mathrm{Na}$ & $\mathrm{Fe}$ \\
\hline APC & 357.4 & 532.0 & 7.2 & 2.4 & 9.9 & 1.6 \\
\hline NPC & 384.2 & 565.0 & 1.1 & 1.3 & 3.6 & 3.9 \\
\hline
\end{tabular}

Table 2

Analysis of the major species present in the filtrates of $10 \mathrm{wt} \%$ aqueous suspensions of APC and NPC.

\begin{tabular}{|c|c|c|c|c|c|}
\hline \multirow[t]{2}{*}{ Solid } & \multicolumn{5}{|c|}{ Concentration $\left(\mathrm{mg} \mathrm{kg}^{-1}\right)$} \\
\hline & $\mathrm{Ca}$ & $\mathrm{Mg}$ & $\mathrm{Na}$ & $\mathrm{Cl}$ & $\mathrm{S}$ \\
\hline APC & 809.2 & 74.6 & 482.7 & 1830.0 & 286.4 \\
\hline NPC & 29.8 & 5.3 & 38.2 & 40.0 & 30.1 \\
\hline
\end{tabular}

suspensions of $10 \mathrm{wt} \%$ of APC and NPC were prepared. They were then filtered and the filtrates were analyzed by ICP-AES and ion chromatography (Table 2). The results obtained confirmed that chlorine-containing and sulfur-containing compounds were more present in APC than in NPC.

The specific surface area $\left(S_{B E T}\right)$ of the solid before and after dispersing in the aqueous solution was analyzed by BET method (Table 3 ). Both APC and NPC were non-porous solids with low specific surface area. No significant change was observed for NPC after dispersion in an aqueous suspension. For APC, the specific surface area slightly increased from 2 to $5 \mathrm{~m}^{2} \mathrm{~g}^{-1}$, probably due to the leaching of various species as shown in Table 2. For comparison, the commercial calcite used in this work was also non-porous and had the specific surface area of $2 \mathrm{~m}^{2} \mathrm{~g}^{-1}$.

XRD analysis (not shown in this paper) showed that calcite was the principal crystalline phase of calcium carbonate [16]. The presence of calcite in NPC and APC is also confirmed by FTIR analysis (Fig. 4). All samples had the characteristic peaks of calcite at 1390, 872 and $712 \mathrm{~cm}^{-1}$. Commercial calcite and NPC showed another small characteristic peak at $848 \mathrm{~cm}^{-1}$. No presence of vaterite was identified [19]. The peak at $854 \mathrm{~cm}^{-1}$ in APC is characteristic of aragonite, a polymorph of calcium carbonate. Peaks at 1136 and $1012 \mathrm{~cm}^{-1}$ which were due to the presence of $\mathrm{CaSO}_{4}$-based compounds (anhydrite, basanite: $\mathrm{CaSO}_{4} \cdot 0.5 \mathrm{H}_{2} \mathrm{O}$, and gypsum: $\mathrm{CaSO}_{4} \cdot 2 \mathrm{H}_{2} \mathrm{O}$ ) were also observed for APC [20].

\subsection{Influence of stirring speed}

Stirring speed is a hydrodynamic parameter that impacts the mass transfer. Fig. 5 shows the dependency of the efficiency on the stirring speed. According to Whitman's theory, transfer coefficient $k$ is directly proportional to the diffusion coefficient and inversely proportional to the film thickness $(k=D / \delta)$. The stirring speed improves the turbulence reducing $\delta$ and increasing $k$ (for both gas-liquid and solid-liquid transfer). Also, the stirring speed can improve gas-liquid mass transfer by increasing the gas-liquid interfacial area $a$ and the gas hold-up.

Fig. 5 shows that APC was more reactive than NPC. Adsorption must be negligible because of the low specific surface of the solids. On the

Table 3

Specific surface areas of the raw solids (before) and the solids after dispersing in an aqueous suspension (after).

\begin{tabular}{lllllll}
\hline Solid & NPC & & APC & & \multicolumn{2}{c}{ Commercial calcite } \\
\hline$S_{B E T}\left(\mathrm{~m}^{2} \mathrm{~g}^{-1}\right)$ & Before & After & Before & After & Before & After \\
& 3 & 4 & 2 & 5 & 2 & 2 \\
\hline
\end{tabular}

other hand, the chemical absorption of $\mathrm{H}_{2} \mathrm{~S}$ by species from the dissolution of the solid must be considered. The solid dissolution rate $J_{B}$ is described by the Noyes-Whitney equation [17]:

$J_{B}=k_{S} a_{S}\left(C_{B S}-C_{B}\right)$

where $k_{S}$ is the solid-liquid mass transfer coefficient, $a_{S}$ is the solidliquid interfacial area per unit of volume, $C_{B S}$ is the saturated solubility of the solid in dissolution media and $C_{B}$ is the concentrations of the solid in dissolution media.

$k_{S}$ can be strongly influenced by stirring speed. It is usually estimated by the Sherwood equation [21]:

$S h=c S c^{n 1} R e^{n 2}$

where $S h, R e$ and $S c$ are the Sherwood, Reynolds and Schmidt dimensionless numbers. Sherwood number represents the ratio of the mass transfer rate to the diffusive rate. Schmidt number is the ratio of kinematic viscosity to the diffusive rate. Reynolds number depends on stirring speed. $c, n 1$ and $n 2$ are constants whose values depends on Re. The viscosity and density of the suspensions are involved in the dimensionless numbers. These properties can be considered similar in both cases. Thus, the influence of the agitation on $R e$ and consequently on $k_{S}$ is similar for both NPC and APC $\left(0.710^{-5} \leq k_{S} \leq 310^{-5} \mathrm{~m} / \mathrm{s}\right.$ depending on the speed agitation).

Considering the fact that all solids particles are under suspension, $a_{S}$ is not affected by the stirring speed. However, $a_{S}$ and $C_{B s}$ of the two solid wastes were different from each other. APC was more soluble and had more impurities than NPC. For this reason, APC had a higher dissolution rate than NPC. In consequence, APC were more available to react with $\mathrm{H}_{2} \mathrm{~S}$ in the liquid media.

\subsection{Influence of solid loading and suspension volume}

Aqueous suspensions containing various contents of solid wastes were tested for the removal of $\mathrm{H}_{2} \mathrm{~S}$. In the range of $0.2-9.5 \mathrm{wt} \%$ of solid, the initial $\mathrm{pH}$ of the suspensions varied slightly from 9.5 to 9.9. In all cases, the final $\mathrm{pH}$ of the suspension was found within the $\mathrm{pH}$ range of 8-9 thanks to the omnipresence of $\mathrm{CaCO}_{3}$-based particles which conditioned the $\mathrm{pH}$ of the suspension. The effect of ionic strength on gas solubility was assumed negligible.

Fig. 6(a) shows the efficiency of $\mathrm{H}_{2} \mathrm{~S}$ removal as a function of the solid loading in aqueous suspension. For both solid wastes, the efficiency of the system increased with the increase of the solid loading. At $2.5 \mathrm{wt} \%$ of solid loading, the reactivity of these solid wastes was found to be higher than that of the commercial calcite. For each solid loading and under the similar operational conditions, APC also showed higher reactivity compared to that of NPC. The highest efficiency of $\mathrm{H}_{2} \mathrm{~S}$ removal reached 95 and $98 \%$ at 5 and $10 \mathrm{wt} \%$ of APC, respectively. These values were close to the thermodynamic equilibrium of $\mathrm{H}_{2} \mathrm{~S}$ in the aqueous and the gas phases. The difference on the reactivity of these solid wastes can be explained by their composition and structure. As mentioned before, APC was more soluble than NPC. Thus, the suspension of APC contained more reactive soluble species than that of NPC. These species, in particular metallic cations such as $\mathrm{Ca}^{2+}, \mathrm{Mg}^{2+}$, can catalyze the oxidation of sulfide-based species $\left(\mathrm{S}^{2-}, \mathrm{HS}^{-}\right)$into sulfur compounds of higher oxidation state (elemental sulfur for example) [22]. In addition, carbonate anions $\left(\mathrm{CO}_{3}{ }^{2-}\right)$, which were more available in the suspension of APC, could also neutralize soluble species of $\mathrm{H}_{2} \mathrm{~S}_{(\mathrm{aq}) \mathrm{s}}$. This will be discussed in the next section.

Fig. 6(b) shows the influence of suspension volume of APC on the removal of the $\mathrm{H}_{2} \mathrm{~S}$. For each solid loading, $\mathrm{H}_{2} \mathrm{~S}$ removal increased with the increase of suspension volume. However, the effect of suspension volume was less important at high solid loading because the abatement got close to the thermodynamic limit, as mentioned above. 

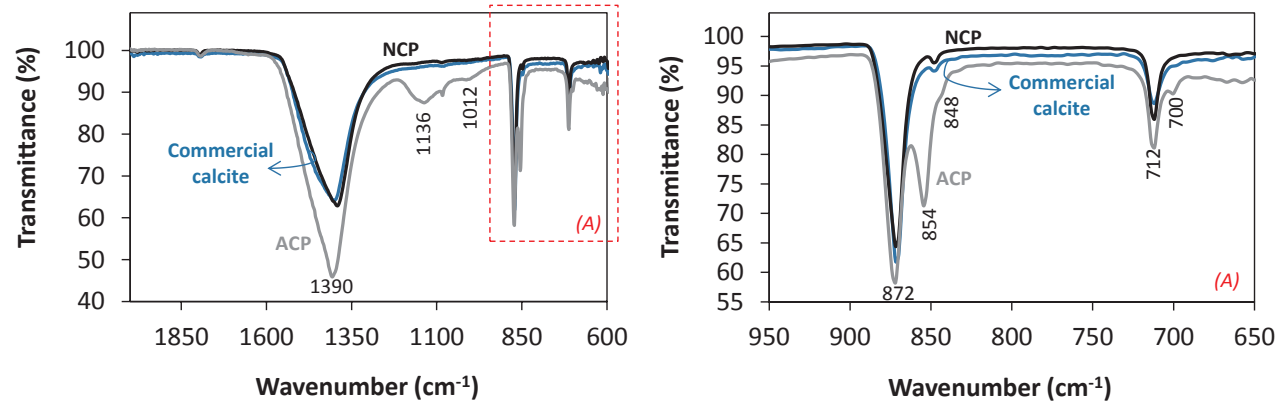

Fig. 4. FTIR spectra of APC, NPC and pure commercial calcite.

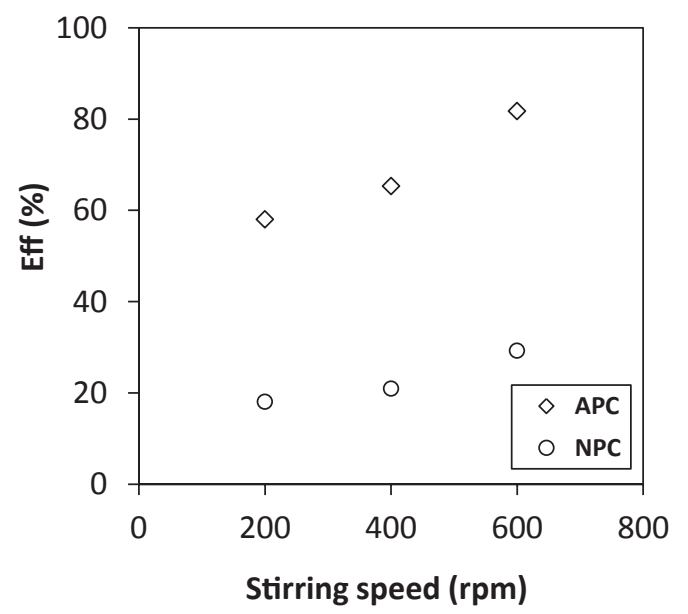

Fig. 5. Influence of the stirring speed on the efficiency of $\mathrm{H}_{2} \mathrm{~S}$ removal. Conditions: Gas flow rate of $100 \mathrm{~mL} \mathrm{~min}^{-1}$, inlet concentration of $\mathrm{H}_{2} \mathrm{~S}$ of 200 ppmv, suspension volume of $100 \mathrm{~mL}$, solid loading of $0.2 \mathrm{wt} \%$, room temperature and pressure; reaction time of at least $8 \mathrm{~h}$ for each test.

\subsection{Influence of the inlet concentration of $\mathrm{H}_{2} \mathrm{~S}$}

The influence of the inlet concentration of $\mathrm{H}_{2} \mathrm{~S}$ on the efficiency of the process is presented in Fig. 7. At the same inlet gas flow rate, the increase of concentration of $\mathrm{H}_{2} \mathrm{~S}$ led to the increase of the rate of $\mathrm{H}_{2} \mathrm{~S}$ removal (mmol min ${ }^{-1}$, Fig. 7(a)). According to Henry's law, the solubility of a gas in a liquid is directly proportional to its partial pressure. As the inlet concentration of $\mathrm{H}_{2} \mathrm{~S}$ increased, the concentration of soluble

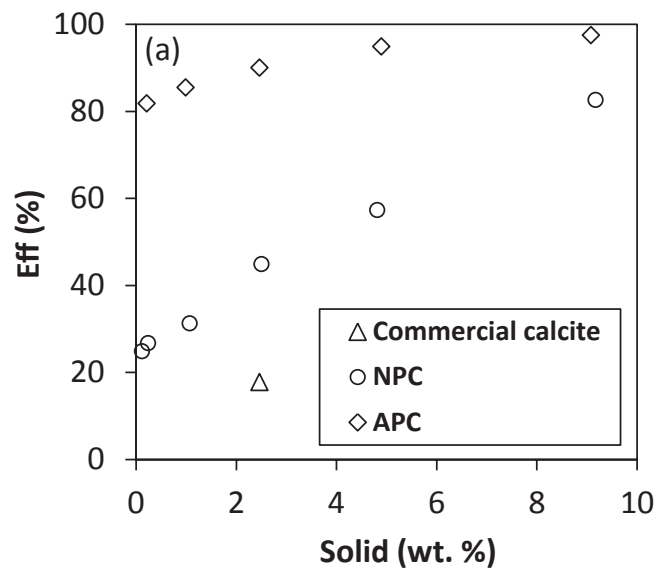

$\mathrm{H}_{2} \mathrm{~S}$ increased. This favored the rate of $\mathrm{H}_{2} \mathrm{~S}$ removal.

Fig. 7(b) presents the efficiency of $\mathrm{H}_{2} \mathrm{~S}$ removal as defined by Eq. (1). We found again that for each inlet concentration of $\mathrm{H}_{2} \mathrm{~S}$ and under similar reaction conditions, APC was more reactive than NPC. For the suspension of NPC, $\mathrm{H}_{2} \mathrm{~S}$ removal was close to $21 \%$ regardless the inlet concentration of $\mathrm{H}_{2} \mathrm{~S}$. On the other hand, $\mathrm{H}_{2} \mathrm{~S}$ removal increased practically linearly with the suspension of APC, explained by the high reactivity of APC suspension.

\subsection{Test of long reaction time}

Fig. 8(a) shows the efficiency of $\mathrm{H}_{2} \mathrm{~S}$ removal for 7 days test using the suspension containing only $0.2 \mathrm{wt} \%$ of APC. The choice of this diluted solution was for evaluating the sorbent saturation and/or the loss of reactivity of the suspension within a reasonable time of test (7 days). The first visual observation was the progressive consumption of APC particles. After 7 days of reaction, when the experiment was stopped, the solution was practically transparent. No solid particles were observed in suspension. There was only some "grey foam", which was deposited on the walls of the reactor (Fig. 8(d)).

Fig. 8(a) shows that $\mathrm{H}_{2} \mathrm{~S}$ removal decreased with the reaction time from around $82 \%$ at the first day to around $32 \%$ at the last day of test. According to the consumption of APC particles, we suppose that the decrease of $\mathrm{H}_{2} \mathrm{~S}$ removal must be related to the unavailability of reactive APC particles. APC particles were likely consumed during the test and this consumption was nearly completed after 7 days of test, under the reaction conditions used. After 7 days of test, the accumulated quantity of removed $\mathrm{H}_{2} \mathrm{~S}$ reached $15 \mathrm{mg}$; the quantity of APC in this test being $200 \mathrm{mg}$ for preparing $100 \mathrm{~mL}$ of suspension of $0.2 \mathrm{wt} \%$. This means that the capacity of APC for $\mathrm{H}_{2} \mathrm{~S}$ abatement according to this

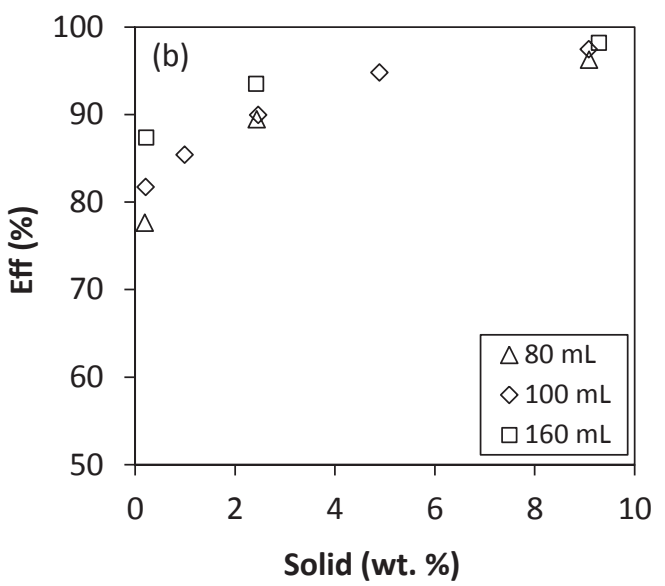

Fig. 6. (a) Efficiency of $\mathrm{H}_{2} \mathrm{~S}$ removal at different solid loading. Conditions: Gas flow rate of $100 \mathrm{~mL} \mathrm{~min}^{-1}$, inlet concentration of $\mathrm{H}_{2} \mathrm{~S}$ of 200 ppmv, suspension volume of $100 \mathrm{~mL}$, stirring speed of $600 \mathrm{rpm}$, room temperature and pressure. (b) Efficiency of $\mathrm{H}_{2} \mathrm{~S}$ removal as a function of suspension volume of APC. Gas flow rate of $100 \mathrm{~mL} \mathrm{~min}^{-1}$, inlet concentration of $\mathrm{H}_{2} \mathrm{~S}$ of $200 \mathrm{ppmv}$, stirring speed of $600 \mathrm{rpm}$, room temperature and pressure; reaction time of at least $8 \mathrm{~h}$ for each test. 

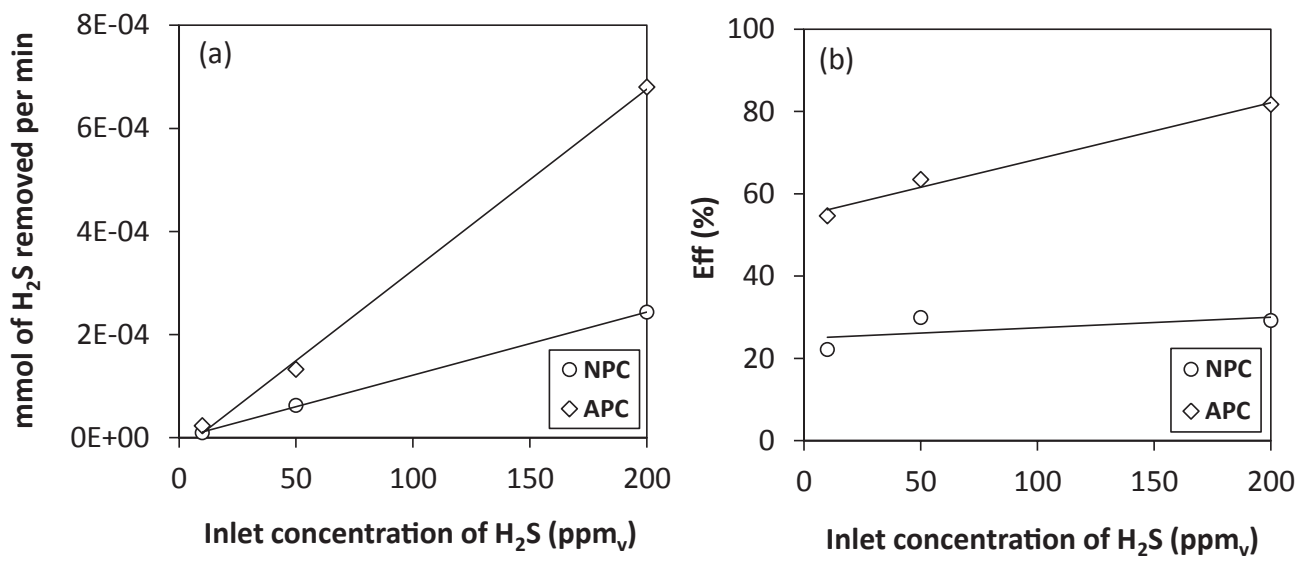

Fig. 7. Influence of the inlet concentration of $\mathrm{H}_{2} \mathrm{~S}$. Conditions: Gas flow rate of $100 \mathrm{~mL} \mathrm{~min}{ }^{-1}$, solid loading of $0.2 \mathrm{wt} \%$, suspension volume of $100 \mathrm{~mL}$, stirring speed of $600 \mathrm{rpm}$, room temperature and pressure; (a) rate of $\mathrm{H}_{2} \mathrm{~S}$ removal (mmol min ${ }^{-1}$ ); (b) Efficiency of $\mathrm{H}_{2} \mathrm{~S}$ removal (\%); reaction time of at least $8 \mathrm{~h}$ for each test.

triphasic process can reach at least $75 \mathrm{mg}$ per $\mathrm{g}$ of sorbent. This offers a new alternative solution to the conventional sorbents based on carbonaceous materials [23-25]. For example, Elsayed et al. [23] showed that the sorption capacity of different activated carbons for the removal of $\mathrm{H}_{2} \mathrm{~S}$ in humidified air varied in the range of $4.2-65.9 \mathrm{mg}$ of $\mathrm{H}_{2} \mathrm{~S}$ per $\mathrm{g}$ of sorbent.

"Foam" recovered from the walls of the reactor at the end of test was characterized by FTIR (Fig. 9) and SEM-EDX (Fig. 10). Fig. 9 compares the FTIR spectrum of the fresh APC with that of foam recovered after 7 days of test. Calcite was still found as the main component of foam. However, the peak of aragonite at $854 \mathrm{~cm}^{-1}$ was strongly reduced indicating that calcium carbonate dissolution really took place during the reaction. However, no notable signal was recorded for sulfur-based compounds by FTIR.

Fig. 10 compares SEM images of foam recovered after 7 days of test

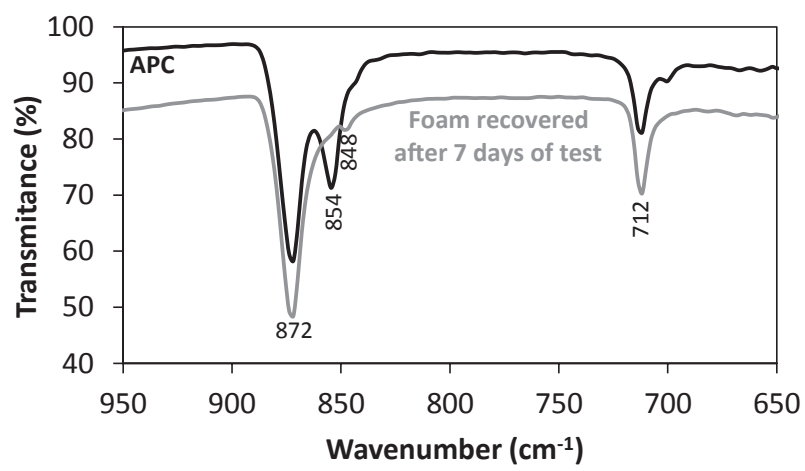

Fig. 9. FTIR spectra of fresh APC and foam recovered after 7 days of test.
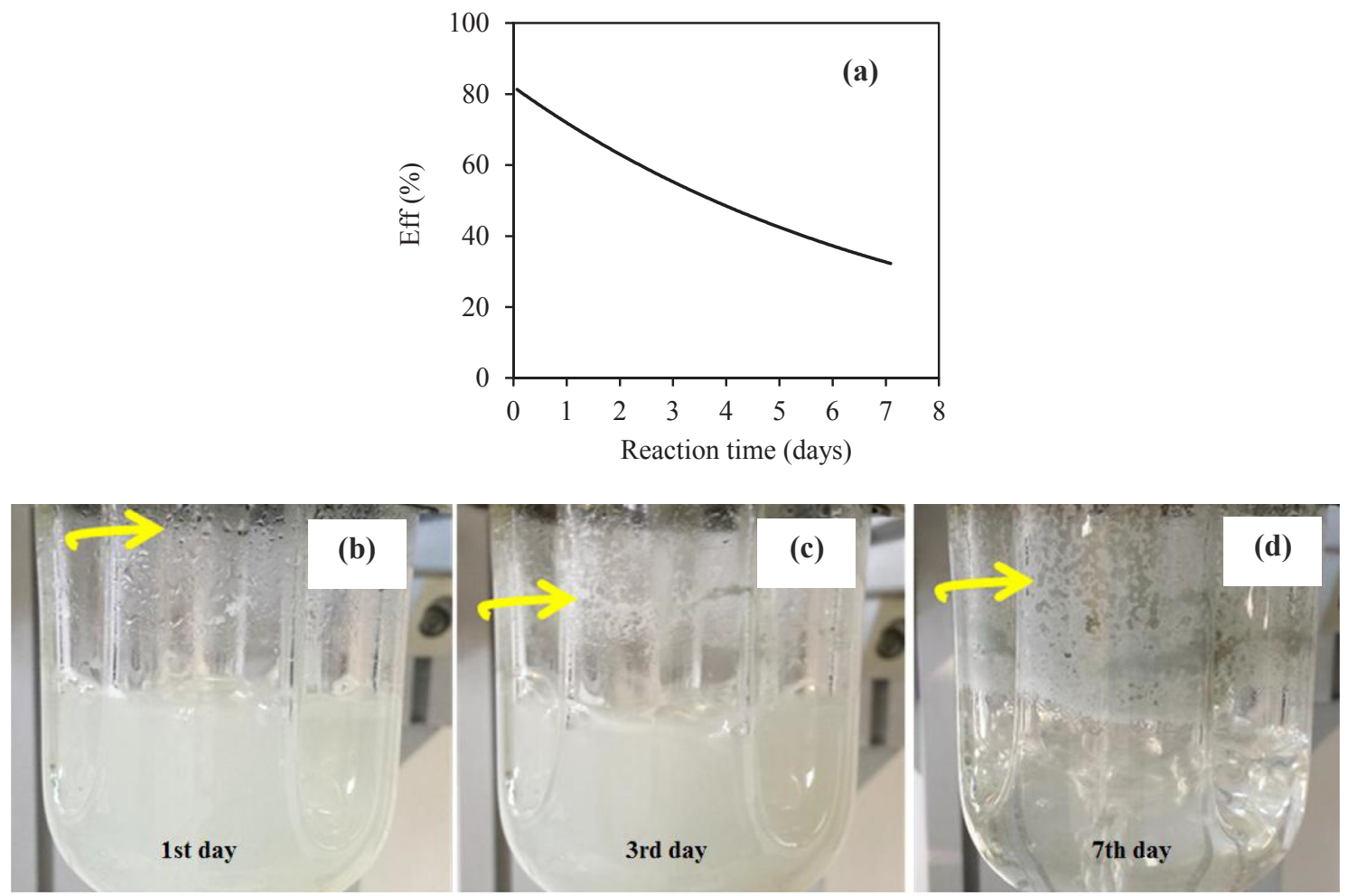

Fig. 8. (a) Efficiency of $\mathrm{H}_{2} \mathrm{~S}$ removal during 7 days of test with APC. Conditions: Gas flow rate of $100 \mathrm{~mL} \mathrm{~min}^{-1}$, inlet concentration of $\mathrm{H}_{2} \mathrm{~S}$ of $200 \mathrm{ppmv}$, solid content of $0.2 \mathrm{wt} \%$, suspension volume of $100 \mathrm{~mL}$, stirring speed of $600 \mathrm{rpm}$, room temperature and pressure; (b) and (c) and (d): Photos of the reactor wall after one, three and seven days of test, respectively. 


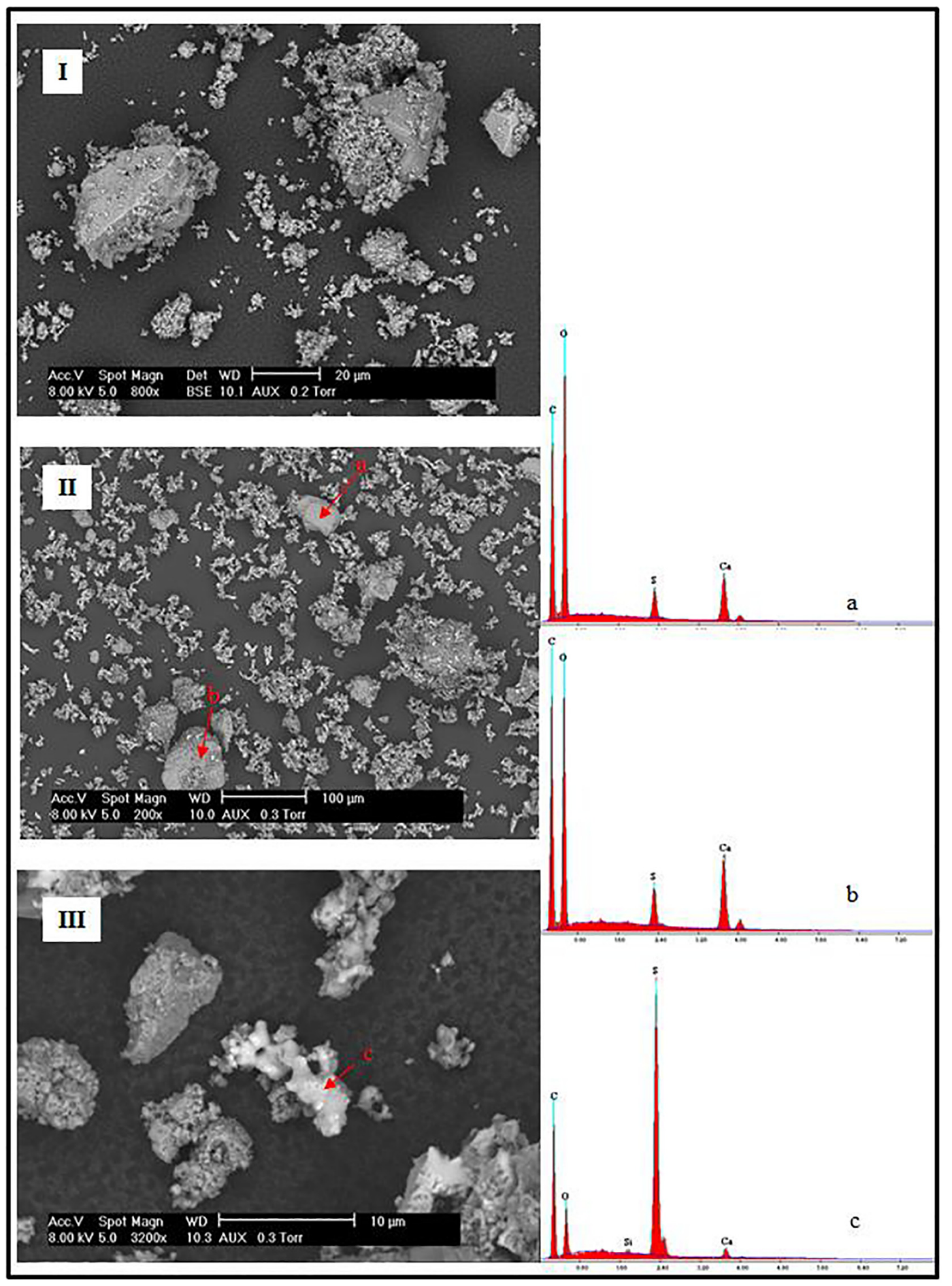

Fig. 10. SEM-EDX analysis of the initial APC (I) and of the foam recovered after 7 days of test (II-III).

with those of the initial APC. The initial APC contained particles and agglomerates of various particle sizes (Fig. 10(I)). Large particles of more than $50 \mu \mathrm{m}$ were usually present in the fresh APC. These large particles were less present in the foam after test (Fig. 10(II)). In addition, particles with high contrast appeared after test (red arrows in Fig. 10(III)). EDX analysis allowed detecting the presence of sulfur for all the spots analyzed (Spots (a) and (b)). However, the concentration of sulfur was particularly important for the analyses on the particles of high contrast (Spot (c)). Imaging of sulfur was built by EDX analysis on a large zone for a global observation on the localization of sulfur species (Fig. 11). This figure strongly evidences the formation of sulfur- containing compounds on the surface of the sorbent after test, and allowed explaining the abatement of $\mathrm{H}_{2} \mathrm{~S}$ from the waste air in Fig. 8.

\subsection{Reaction pathway for $\mathrm{H}_{2} \mathrm{~S}$ abatement}

We have shown that APC and NPC were active for the removal of $\mathrm{H}_{2} \mathrm{~S}$ from the gas phase by a triphasic gas-liquid-solid process. Their performance was higher than that of the commercial calcite from Fisher Scientific. Absorption and adsorption phenomena could take place but they did not explain the plateau of the outlet concentration of $\mathrm{H}_{2} \mathrm{~S}$ as illustrated in Fig. 2. Chemical reactions must occur inside the reaction 

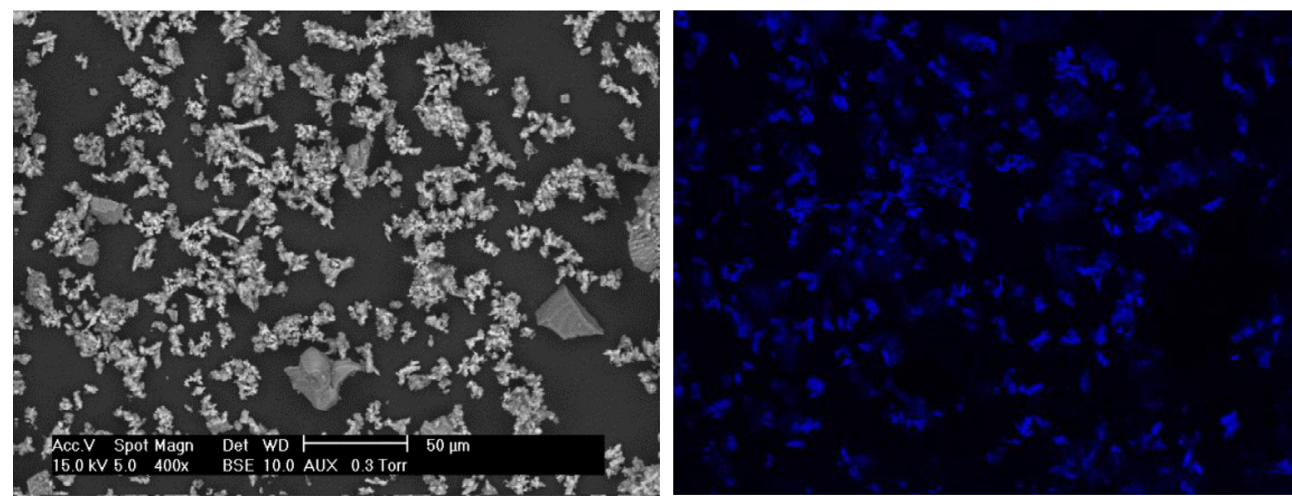

Fig. 11. SEM image (left-hand-side) and imaging of sulfur (right-hand-side, blue color) of the foam recovered after 7 days of test. Images recorded at the same scale.

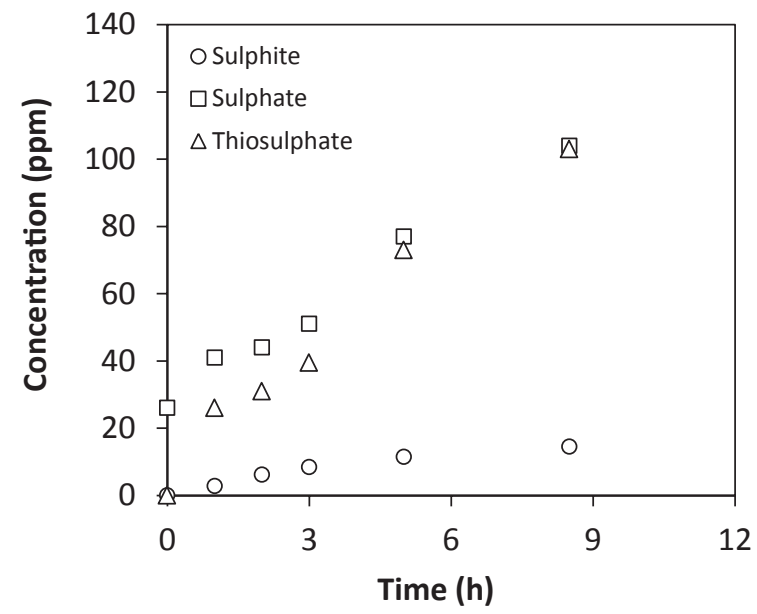

Fig. 12. Evolution of the concentration of sulphur species in the liquid phase. Conditions: air flow rate of $100 \mathrm{~mL} \mathrm{~min}^{-1}$, initial concentration of $\mathrm{H}_{2} \mathrm{~S}$ in waste air of $200 \mathrm{ppmv}, 100 \mathrm{~mL}$ of suspension, $0.2 \mathrm{wt} \%$ of solid using APC as reactive sorbent, room temperature and pressure.

mixture, as suggested thereafter, in parallel with the "consumption" of calcium carbonate particles by these chemical reactions. The main steps suggested for this process are as follows:

- When the waste air passed through the suspension, the dissolution of gaseous $\mathrm{H}_{2} \mathrm{~S}$ and $\mathrm{O}_{2}$ took place (Eqs. (6) and (7)):

$H_{2} S_{(g)} \rightleftarrows H_{2} S_{(a q)}$

$\mathrm{O}_{2(g)} \rightleftarrows \mathrm{O}_{2(a q)}$

- When a solid sorbent was added to the reaction mixture, the dissociation/dissolution of calcium carbonate and other impurities present in the initial solid sorbent occured (Eqs. (8) and (9)), leading to the formation of soluble metallic cations in solution. Different ions such as $\mathrm{Ca}^{2+}, \mathrm{Mg}^{2+}, \mathrm{Cl}^{-}, \mathrm{SO}_{4}{ }^{2-}$ were identified in aqueous suspension of calcium carbonate-based solids (Table 2):

$\mathrm{CaCO}_{3(s)} \rightleftarrows \mathrm{Ca}_{(a q)}^{2+}+\mathrm{CO}_{3(a q)}^{2-}$

$M_{x} A_{y(s)} \rightleftarrows x M_{(a q)}^{n+}+y A_{(a q)}^{m-}$

- In the liquid phase, there was the dissociation and formation of different anions:

$\mathrm{H}_{2} \mathrm{~S}_{(a q)}+\mathrm{H}_{2} \mathrm{O} \rightleftarrows H S_{(a q)}^{-}+\mathrm{H}_{3} \mathrm{O}_{(a q)}^{+}$

$\mathrm{HS}_{(a q)}^{-}+\mathrm{H}_{2} \mathrm{O} \rightleftarrows \mathrm{S}^{2-}+\mathrm{H}_{3} \mathrm{O}_{(a q)}^{+}$
$\mathrm{H}_{2} \mathrm{~S}_{(a q)}+\mathrm{CO}_{3(a q)}^{2-} \rightleftarrows H S_{(a q)}^{-}+\mathrm{HCO}_{3(a q)}^{-}$

$\mathrm{HS}_{(a q)}^{-}+\mathrm{CO}_{3(a q)}^{2-} \rightleftarrows S_{(a q)}^{2-}+\mathrm{HCO}_{3(a q)}^{-}$

- Soluble $\mathrm{H}_{2} \mathrm{~S}_{(\mathrm{aq})}$ dissociated and/or reacted with carbonate anions to form other sulfide species (Eqs. (10)-(13)). The dissociation of hydrogensulfide $\left(\mathrm{HS}^{-}\right)$to form sulfide anion $\left(\mathrm{S}^{2-}\right)$ according to Eq. (11) must be negligible at $\mathrm{pH}$ around 9 (which was the $\mathrm{pH}$ of the suspensions prepared from the three sorbents used in this work), taking into account the second $\mathrm{pK}_{\mathrm{a} 2}$ of $\mathrm{H}_{2} \mathrm{~S}$ in an aqueous solution (equal to 13 at $25^{\circ} \mathrm{C}$ ). Thus, the reaction between hydrogensulfide and carbonate anions must be also negligible at pH 9 (Eq. (13)). So, hydrogensulfide $\left(\mathrm{HS}^{-}\right.$) must be the main sulfide species in the solution at this $\mathrm{pH}$. The resulting soluble sulfide species $\left(S_{(a q)}^{n-}\right.$, equivalent to the sum of $\mathrm{H}_{2} S_{(a q)}, H S_{(a q)}^{-}$and $S_{(a q)}^{2-}$ ) were oxidized to higher oxidation states, according to Eq. (14):

$S_{(a q)}^{n-}+O_{2(a q)} \rightleftarrows S_{(s)}+S_{3(a q)}^{2-}+S_{4(a q)}^{2-}+S_{2} O_{3(a q)}^{2-}$

- This oxidation could be catalyzed by: 1) soluble metallic cations in solution including $\mathrm{Ca}^{2+}, \mathrm{Mg}^{2+}$ [22]; and 2) insoluble metals on the surface of the solid $[2,4,22,26]$. The presence of sulfite $\left(\mathrm{SO}_{3}{ }^{2-}\right)$, sulfate $\left(\mathrm{SO}_{4}{ }^{2-}\right)$, and thiosulfate $\left(\mathrm{S}_{2} \mathrm{O}_{3}{ }^{2-}\right)$ were confirmed by analyzing the liquid fraction of the reaction mixture with ionic chromatography (Fig. 12).

- Finally, the precipitation of sulfur species with metallic cations might also occur to form solid precipitates which could be metals sulfite, metals sulfate or metals thiosulfate:

$\mathrm{Ca}_{(a q)}^{2+}+\mathrm{M}_{(a q)}^{n+}+\mathrm{SO}_{3(a q)}^{2-}+\mathrm{SO}_{4(a q)}^{2-}+\mathrm{S}_{2} \mathrm{O}_{3(a q)}^{2-} \rightleftarrows$ solid precipitates

APC was found to be more efficient than NPC under the same experimental conditions. This can be now confirmed by the higher solubility of calcium carbonate present in APC. This calcium carbonate was initially formed by an accelerated process of carbonation and thus was more easily dissolved in an aqueous solution. On the other hand, NPC was formed by the natural atmospheric carbonation process and became more difficult to dissolve. So, the suspension of APC contained more carbonate anions $\left(\mathrm{CO}_{3}{ }^{2-}\right)$ and calcium cations $\left(\mathrm{Ca}^{2+}\right)$, which were both useful for the dissociation of $\mathrm{H}_{2} \mathrm{~S}$ (Eq. (12)) as well as for the precipitation of sulfur species (Eq. (15)). The efficiency of the process decreased with the reaction time (Fig. 5) because calcium carbonate particles were progressively consumed. In addition, solid sulfur species were formed and could limit or prevent the contact of calcium carbonate particles with sulfide species.

According to the mechanism of $\mathrm{H}_{2} \mathrm{~S}$ abatement in Eqs. (6)-(15), the dissolved oxygen must play a very important role in this process. Dissolved oxygen reacted with soluble sulfide species $\left(S_{(a g)}^{n-}\right)$ to form stable sulfite $\left(\mathrm{SO}_{3}{ }^{2-}\right)$, sulfate $\left(\mathrm{SO}_{4}{ }^{2-}\right)$, and thiosulfate $\left(\mathrm{S}_{2} \mathrm{O}_{3}{ }^{2-}\right)$ species. This allows the continuous dissolution of gaseous $\mathrm{H}_{2} \mathrm{~S}$ into the suspension 


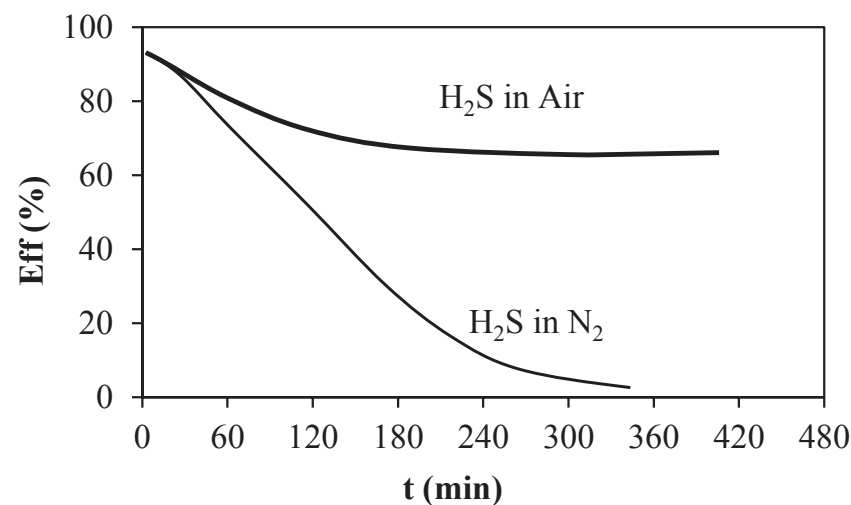

Fig. 13. Role of oxygen in the $\mathrm{H}_{2} \mathrm{~S}$ abatement under the similar experimental condition by using two gas matrices. Conditions: $100 \mathrm{~mL}$ de suspension of APC at $0.2 \mathrm{wt} \%$; $600 \mathrm{rpm}$; gas flow rate of $100 \mathrm{~mL} / \mathrm{min} ; 50$ ppmv d' $\mathrm{H}_{2} \mathrm{~S}$ in $\mathrm{N}_{2}$ or air.

Table 4

Example of results on $\mathrm{H}_{2} \mathrm{~S}$ removal using carbon-based materials.

\begin{tabular}{|c|c|c|c|c|}
\hline Sorbent & $\begin{array}{l}\text { Type of } \\
\text { reactor }\end{array}$ & Medium & $\begin{array}{l}\mathrm{Q}\left(\mathrm{mg}_{\mathrm{H} 2 \mathrm{~S}} /\right. \\
\left.\mathrm{g}_{\text {sorbent }}\right)\end{array}$ & Ref. \\
\hline Activated carbon & Fixed-bed & $\mathrm{H}_{2} \mathrm{~S}$ in dry $\mathrm{N}_{2}$ & 9 & [27] \\
\hline $\begin{array}{l}\text { Char from black } \\
\text { liquor } \\
\text { carbonization }\end{array}$ & $\begin{array}{l}\text { Fluidized } \\
\text { bed }\end{array}$ & $\begin{array}{l}\mathrm{H}_{2} \mathrm{~S} \text { in humidified } \\
\mathrm{N}_{2}\end{array}$ & $25-70$ & [28] \\
\hline Activated carbon & Fixed-bed & $\mathrm{H}_{2} \mathrm{~S}$ in dry air & $5-31$ & [23] \\
\hline $\begin{array}{l}\text { Char from sludge } \\
\text { pyrolysis }\end{array}$ & Fixed-bed & $\begin{array}{l}\mathrm{H}_{2} \mathrm{~S} \text { in humidified } \\
\text { air }\end{array}$ & $6-62$ & {$[2]$} \\
\hline APC and NPC & $\begin{array}{l}\text { Triphasic } \\
\text { G/L/S }\end{array}$ & $\begin{array}{l}\mathrm{H}_{2} \mathrm{~S} \text { in dry air } \\
\text { scrubbed in } \\
\text { suspension of } \\
\mathrm{CaCO}_{3} \text {-based } \\
\text { particles }\end{array}$ & $>75$ & $\begin{array}{l}\text { This } \\
\text { work }\end{array}$ \\
\hline
\end{tabular}

and explains the plateau time of $\mathrm{H}_{2} \mathrm{~S}$ outlet concentration in Fig. 2. To confirm this important role of the dissolved oxygen, two experiments were carried out under the same condition using $\mathrm{H}_{2} \mathrm{~S}(50 \mathrm{ppmv})$ in the synthetic air $\left(20 \% \mathrm{O}_{2}\right.$ and $80 \% \mathrm{~N}_{2}$, vol. $\left.\%\right)$ and in pure $\mathrm{N}_{2}$. Fig. 13 shows the results obtained. After the first minutes of reaction wherein the efficiency of $\mathrm{H}_{2} \mathrm{~S}$ abatement was similar to each of two gas matrices, the efficiency of $\mathrm{H}_{2} \mathrm{~S}$ abatement in the synthetic air reached a plateau time, but this decreased progressively to zero in pure $\mathrm{N}_{2}$. In fact, the initial quantity of dissolved oxygen in $200 \mathrm{~mL}$ of water fed into the reactor was progressively consumed according to Eq. (14) and it was not renewed in the case of $\mathrm{H}_{2} \mathrm{~S}$ diluted in pure $\mathrm{N}_{2}$. Thus, Eq. (14) did not further take place which explained the outlet $\mathrm{H}_{2} \mathrm{~S}$ concentration profile in the case of $\mathrm{H}_{2} \mathrm{~S}$ diluted in pure $\mathrm{N}_{2}$.

\subsection{Comparison with the results reported in the literature}

Carbon-based materials (i.e. activated carbon) are considered as references for $\mathrm{H}_{2} \mathrm{~S}$ removal. Table 4 compares the performance of APC and NPC residues with those of carbon-based materials including activated carbon and biochar. Using fixed-bed or fluidized bed reactors, the capacity for $\mathrm{H}_{2} \mathrm{~S}$ abatement of carbon-based materials is generally below $70 \mathrm{mg}$ of $\mathrm{H}_{2} \mathrm{~S}$ per $\mathrm{g}$ of material [2,27-29], in dry or humidified gas. The residues used in this work showed the comparable reactivity of at least $75 \mathrm{mg}$ of $\mathrm{H}_{2} \mathrm{~S}$ per $\mathrm{g}$ of material.

Caustic scrubbing in the aqueous solution using reactants like $\mathrm{NaOH}, \mathrm{NaClO}, \mathrm{NaHCO}_{3}$ is an efficient technology for the removal of $\mathrm{H}_{2} \mathrm{~S}$ from the gas phase and has the similar operation mode compared to the reactor design of the present work. As a function of the inlet concentration of $\mathrm{H}_{2} \mathrm{~S}$, the feeding of caustic reactants, and the gas flow rate, the abatement of $\mathrm{H}_{2} \mathrm{~S}$ can reach nearly $100 \%[29,30]$. However, the cost of these caustic reactants is largely higher (5-10 times) than that of the residues used in this work [16]. This demonstrates the interest of APC and NPC as the potential materials for $\mathrm{H}_{2} \mathrm{~S}$ removal from the gas phase using the triphasic $\mathrm{G} / \mathrm{L} / \mathrm{S}$ process.

\section{Conclusions}

For the first time, a triphasic gas/liquid/solid process was designed for the abatement of $\mathrm{H}_{2} \mathrm{~S}$ from the gas phase using calcium carbonatecontaining residues from industrial activities as reactive sorbents. Solid wastes containing high calcium carbonate contents under powder form could directly be used as sorbent for $\mathrm{H}_{2} \mathrm{~S}$ abatement after a simple drying at room temperature. At room temperature and ambient pressure, this process was found to be very efficient for the abatement of $\mathrm{H}_{2} \mathrm{~S}$. The dissolution and dissociation of $\mathrm{H}_{2} \mathrm{~S}$ from the gas phase to the liquid phase was of crucial importance, which allowed increasing the contact time of sulfur species with dissolved oxygen for further oxidation into stable sulfite $\left(\mathrm{SO}_{3}{ }^{2-}\right)$, sulfate $\left(\mathrm{SO}_{4}{ }^{2-}\right)$, and thiosulfate $\left(\mathrm{S}_{2} \mathrm{O}_{3}{ }^{2-}\right)$ species. The sorption capacity of APC sorbent could reach at least $75 \mathrm{mg}$ of $\mathrm{H}_{2} \mathrm{~S}$ per gram of sorbent which is very competitive compared to that of the conventional sorbents, i.e. activated carbon.

The next step of this study would be focused on the trials at large industrial pilot scale with a real waste air from a wastewater treatment plant polluted by $\mathrm{H}_{2} \mathrm{~S}$.

\section{Acknowledgments}

The authors gratefully acknowledge the colleagues at RAPSODEE Research Center (UMR CNRS 5302, France) for their technical help.

\section{References}

[1] C.F. Cullis, M.M. Hirschler, Atmospheric sulphur: natural and man-made sources, Atmos. Environ. 14 (1980) 1263-1278.

[2] A. Ros, M.A. Montes-Moran, E. Fuente, D.M. Nevskaia, M.J. Martin, Dried sludges and sludge-based chars for $\mathrm{H}_{2} \mathrm{~S}$ removal at low temperature: influence of sewage sludge characteristics, Environ. Sci. Technol. 40 (2006) 302-309.

[3] H. Pham Xuan, D. Pham Minh, M. Galera Martínez, A. Nzihou, P. Sharrock, Valorization of calcium carbonate-based solid wastes for the treatment of hydrogen sulfide from the gas phase, Ind. Eng. Chem. Res. 54 (2015) 4915-4922.

[4] K. Kim, S. Asaoka, T. Yamamoto, S. Hayakawa, K. Takeda, M. Katayama, T. Onoue, Mechanisms of hydrogen sulfide removal with steel making slag, Environ. Sci. Technol. 46 (2012) 10169-10174.

[5] http://www.atsdr.cdc.gov/toxprofiles/tp114.pdf (accessed on August 06, 2018).

[6] J.H. Seinfeld, S.N. Pandis, Atmospheric Chemistry and Physics: From Air Pollution to Climate Change, Wiley, New York, 2012.

[7] P.-F. Biard, A. Couvert, C. Renner, P. Zozor, S. Bassivière, J.-P. Levasseur, Hydrogen sulphide removal in waste water treatment plant by compact oxidative scrubbing in Aquilair Plus ${ }^{\mathrm{TM}}$ process, Water Pract. Technol. 4 (2) (2009) wpt2009023.

[8] A. Kerc, S.S. Olmez, Ozonation of odorous air in wastewater treatment plants, J. Inter. Ozone Assoc. 32 (2010) 199-203.

[9] L. Wu, Y.Y. Loo, L.C. Koe, A pilot study of a biotrickling filter for the treatment of odorous sewage air, Water Sci. Technol. 44 (2001) 295-299.

[10] H.H.J. Cox, M.A. Deshusses, B.M. Converse, E.D. Schroeder, R. Iranpour, Odor and volatile organic compound treatment by biotrickling filters: pilot-scale studies at Hyperion treatment plant, Water Env. Res. 74 (2002) 557-563.

[11] C. Van der Heyden, P. Demeyer, E.I.P. Volcke, Mitigating emissions from pig and poultry housing facilities through air scrubbers and biofilters: state-of-the-art and perspectives, Biosystems Eng. 134 (2015) 74-93.

[12] A. Kirchofer, A. Brandt, S. Krevor, V. Prigiobbe, A. Becker, J. Wilcox, Assessing the potential of mineral carbonation with industrial alkalinity sources in the U.S, Energy Procedia 37 (2013) 5858-5869.

[13] Q. Liu, M.M. Maroto-Valer, Experimental studies on mineral sequestration of $\mathrm{CO}_{2}$ with buffer solution and fly ash in brines, Energy Procedia 37 (2013) 5870-5874.

[14] V. Filippova, P. Piriou, L. Filippov, J. Yvon, M. Grandjean, Carbonation of residual brines produced by ammonia-soda process, J. Phys. Conf. Ser. 416 (2013) 012014.

[15] Y. Soong, D.L. Fauth, B.H. Howard, J.R. Jones, D.K. Harrison, A.L. Goodman, M.L. Gray, E.A. Frommell, $\mathrm{CO}_{2}$ sequestration with brine solution and fly ashes, Ener. Convers. Manage. 47 (2006) 1676-1685.

[16] M. Galera-Martinez, Valorisation des residus carbonates industriels pour le traitement de sulfure d'hydrogene dans les effluents gazeux, University of Toulouse, 2015 (Ph.D. thesis)

[17] E.L. Cussler, Diffusion: Mass Transfer in Fluid Systems, thirrd ed., Cambridge University Press, New York, 2009.

[18] J.-B. Vilmain, V. Courousse, P.-F. Biard, M. Azizi, A. Couvert, Kinetic study of hydrogen sulfide absorption in aqueous chlorine solution, Chem. Eng. Res. Des. 92 (2014) 191-204. 
[19] M. Sato, S. Matsuda, Structure of vaterite and infrared spectra, Z. Kristallogr. 129 (1969) 405-410.

[20] M. Grandjean, L. Filippov, I. Filippova, O. Barres, M. Pelletier, J. Ghanbaja, Reactivity and valorization of products issued from carbonation of saline waste solution, Waste Biomass Valorization 4 (2012) 831-841.

[21] H.D. Baehr, K. Stephan, Heat and Mass Transfer, Springer-Verlag, Berlin Heidelberg, 2011.

[22] J.W. Morse, F.J. Millero, J.C. Cornwell, D. Rickard, The chemistry of the hydrogen sulfide and iron sulfide systems in natural waters, Earth Sci. Rev. 24 (1987) 1-42.

[23] Y. Elsayed, M. Seredych, A. Dallas, T.J. Bandosz, Desulfurization of air at high and low $\mathrm{H}_{2} \mathrm{~S}$ concentrations, Chem. Eng. J. 155 (2009) 594-602.

[24] X. Xiao, D.D. Le, L. Li, X. Meng, J. Cao, K. Morishita, T. Takarada, Catalytic steam gasification of biomass in fluidized bed at low temperature: conversion from livestock manure compost to hydrogen-rich syngas, Biomass Bioener. 34 (2010) $1505-1512$.

[25] M. Hervy, D. Pham Minh, C. Gérente, E. Weiss-Hortala, A. Nzihou, A. Villot, L. Le Coq, $\mathrm{H}_{2} \mathrm{~S}$ removal from syngas using wastes pyrolysis chars, Chem. Eng. J. 334
(2018) 2179-2189.

[26] H. Tian, J. Wu, W. Zhang, S. Yang, F. Li, Y. Qi, R. Zhou, X. Qi, L. Zhao, X. Wang, High performance of $\mathrm{Fe}$ nanoparticles/carbon aerogel sorbents for $\mathrm{H}_{2} \mathrm{~S}$ removal, Chem. Eng. J. 313 (2017) 1051-1060.

[27] Y. Xiao, S. Wang, D. Wu, Q. Yuan, Catalytic oxidation of hydrogen sulfide over unmodified and impregnated activated carbon, Separ. Purif. Technol. 59 (2008) $326-332$.

[28] Y. Sun, J.P. Zhang, C. Wen, L. Zhang, An enhanced approach for biochar preparation using fluidized bed and its application for $\mathrm{H}_{2} \mathrm{~S}$ removal, Chem. Eng. Proc. 104 (2016) 1-12.

[29] J. Krischan, A. Makaruk, M. Harasek, Design and scale-up of an oxidative scrubbing process for the selective removal of hydrogen sulfide from biogas, J. Hazard. Mat. 215-216 (2012) 49-56

[30] P.-F. Biard, A. Couvert, C. Renner, J.-P. Levasseur, Wet scrubbing intensification applied to hydrogen sulphide removal in waste water treatment plant, Canad. J. Chem. Eng. 88 (2010) 682-687. 